\title{
The Relationship between the Feature of Thyroid Calcification and Thyroid Papillary Cancer
}

\author{
Nam Hoon Lee, Hyun Jin Choi, Seh Hyung Huh, Chang Hee Lee, Sung Min Jin and Sang Hyuk Lee \\ Department of Otorhinolaryngology-Head and Neck Surgery, Kangbuk Samsung Medical Center, \\ Sungkyunkwan University School of Medicine, Seoul, Korea
}

\section{갑상선 종물 내 석회화 양상과 유두상암과의 연관성}

이남훈·최현진 · 허세형 · 이창희 · 진성민 · 이상혁

성균관대학교 의과대학 강북삼성병원 이비인후과학교실

\author{
Received June 22, 2009 \\ Revised September 1, 2009 \\ Accepted September 28, 2009 \\ Address for correspondence \\ Sang Hyuk Lee, MD \\ Department of Otorhinolaryngology- \\ Head and Neck Surgery, \\ Kangbuk Samsung Medical Center, \\ Sungkyunkwan University \\ School of Medicine, \\ 78 Saemunan-gil, Jongno-gu, Seoul \\ 110-746, Korea \\ Tel $+82-2-2001-2269$ \\ Fax $+82-2-2001-2273$ \\ E-mailentlsh@hanmail.net
}

Backgraound and Objectives Thyroid calcification is widely known as a highly specific sign of malignancy. However, there are few studies on the correlation between the calcification and papillary thyroid cancer (PTC). The aim of this study was to describe the features of calcification in thyroid mass, and determine the relationship between thyroid calcification and PTC.

Subjects and Methods Patients (116) who underwent surgery for thyroid mass during the period of March 2006 to December 2008 were reviewed retrospectively. Each patient underwent preoperative sonography $(n=96)$ and computed tomography $(C T)(n=110)$ to evaluate the thyroid lesion. We subdivided the calcification according to characteristic features and compared the pathologic results. The association between the type of calcification and PTC was verified through the Chi-square test or likelihood ratio.

Results Of 96 patients who underwent sonography, 41 (42.7\%) had calcification, of which 23 had microcalcificaiton, 15 had focal calcification, and three had rim calcification. Of 41 calcified lesions, $34(82.9 \%)$ were PTC. Incidence of cancer from thyroid which had no calcified lesion was $30.9 \%$. Three $(6.7 \%)$ of 45 benign lesions had microcalcification, and $20(39.2 \%)$ of 51 were PTC. We found statistically significant correlation between the presence of calcification, especially microcalcification, on sonography and PTC. Thirty of 110 patients $(27.3 \%)$ who underwent neck CT had calcification, and among them, 20 patients $(66.7 \%)$ were diagnosed as PTC. There was no statistical significance in relationship between calcification on CT and malignancy.

Conclusion This study suggests that microcalcification which is shown by sonography were more specific for PTC than other calcified lesions.

Korean J Otorhinolaryngol-Head Neck Surg 2009;52:893-8

Key Words Thyroid carcinoma - Calcification · Ultrasonography · Computed tomography.

\section{서 론}

갑상선 결절은 비교적 흔한 질환으로 성인에서의 발생 빈 도는 2 7\%로 보고되고 있으며, 무작위로 고해상도 초음 파검사를 시행한 결과 여성의 $50 \%$ 이상에서 갑상선 결절 이 발견되었다는 보고도 있다. ${ }^{1-3)}$ 대부분 양성이나 약 $10 \%$ 미만에서 악성 종양이 발생하며, 그 중 유두상암이 전체 갑
상선 암의 80 90\% 정도를 차지한다. ${ }^{3)}$ 그러나 갑상선 결 절은 악성 종양이라도 조기의 적절한 외과적 적출시 다른 종양보다 훨씬 좋은 예후를 보이기 때문에 치료에 있어 결 절의 악성과 양성의 감별은 매우 중요하다.,4)

현재 갑상선 결절의 진단에는 초음파검사, 전산화단층촬 영 같은 영상학적 방법이 많이 시행되고 있으며 이를 통해 발견되는 석회화 소견은 결절의 감별에 큰 도움이 되고 있 
다. 초음파검사는 갑상선 결절의 석회화를 발견하고 파악 하는 데 가장 민감한 검사법으로, 다양한 석회화 양상 중 특히 미세석회화는 다른 소견들보다 악성 결절과의 상대적 으로 높은 연관성 때문에 주목 받고 있다. ${ }^{5)}$ 그러나 석회화 는 양성 및 악성의 갑상선 질환에서 모두 관찰이 가능하고 유두상암과의 연관성에 관한 많은 보고가 있지만 임상적 중요성은 아직 논란이 많은 상태이다. ${ }^{6)}$

이에 저자들은 본원 이비인후과에서 갑상선 종물로 수술 을 받은 환자들을 대상으로 수술 전 시행한 경부 초음파검 사와 경부 전산화단층촬영에서 확인된 석회화의 빈도와 양 상을 분석하여 갑상선 유두상암과의 연관성에 대해 알아보 고자 하였다.

\section{대상 및 방법}

2006년 3월부터 2008년 12월까지 본원 이비인후과에 서 갑상선 종물로 수술을 받은 환자 중 의무기록의 분석이 가능하고 조직병리학적으로 확진된 116 명을 대상으로 후 향적 분석을 시행하였다. 갑상선 수술의 적응증은 수술 전 시행한 세침흡인검사에서 악성이 확인된 경우, 세침흡인검 사에서 진단이 불분명한 경우 환자의 현 병력과 위험인자, 초음파검사를 고려하여 수술을 진행하였으며 세침흡인검사 상 양성으로 확인된 경우 결절의 크기가 커서 환자가 미용 상의 이유로 수술을 원하는 경우, 기도를 압박하는 경우, 크기의 현격한 증가가 있는 경우 등이다. 평균연령은 50.0 세였으며 남자가 32명 (27.6\%), 여자가 84명 (72.4\%)이 었고 그 중 양성 결절은 54명 $(46.6 \%)$, 유두상암은 62 명 (53.4\%)이었다. 수술 전 경부 초음파검사를 96명, 경부 전
산화단층촬영은 110 명이 시행 받았으며 영상의학과 전문의 의 석회화 유무와 양상의 판독한 내용을 저자들이 확인, 분 석하였고, 그 중 과거 판독 소견이 부정확하거나 본 연구와 형식이 맞지 않는 경우 술 후 최종 조직병리 결과의 언급 없 이 재의뢰하여 분석하였다.

경부 초음파검사에서 관찰되는 석회화는 3 가지 형태로 분 류하였다. ${ }^{7}$ 후방음영을 보이진 않지만 지름이 $2 \mathrm{~mm}$ 미만 의 더 작은 강한 고에코를 보이는 미세석회화(Fig. 1A), 지 름 $2 \mathrm{~mm}$ 이상의 후방 음영을 갖는 고에코가 모여있거나 따로 떨어져 있는 국소 석회화(Fig. 1B), 그리고 갑상선 결 절을 둘러싸는 고에코를 보이는 변연부 석회화(Fig. 1C)로 나누었다. 경부 전산화단층촬영에서 관찰되는 석회화 소견 도 유두상암과의 연관성을 평가하기 위해 결절 내 석회화와 변연부 석회화로 분류하였다. 또한 환자 연령에 따른 석회 화와 유두상암과의 연관성을 알아보기 위하여 석회화 소견이 있는 군을 40세 미만군과 이상군으로 나누어 분석하였다.

통계적 유의성 검정은 SPSS stastics 17.0 (SPSS inc., Chicago, Illinois) 를 이용하여 Chi-square test, Fisher's exact test 통해 실시하였으며 교차비(odds ratio)를 통해 상대적 위험도를 평가하였다. 통계 수치는 $p<0.05$ 를 통계 학적으로 의미 있는 것으로 보았다.

\section{결 과}

\section{갑상선 종물 내 석회화 양상과 유두상암과의 연관성}

경부 초음파검사를 시행한 환자 96예 중 41예(42.7\%)에 서 석회화가 관찰되었으며 그 중 미세석회화는 23예(56.1\%), 국소 석회화는 15예(36.6\%), 변연부 석회화는 3예(7.3\%)
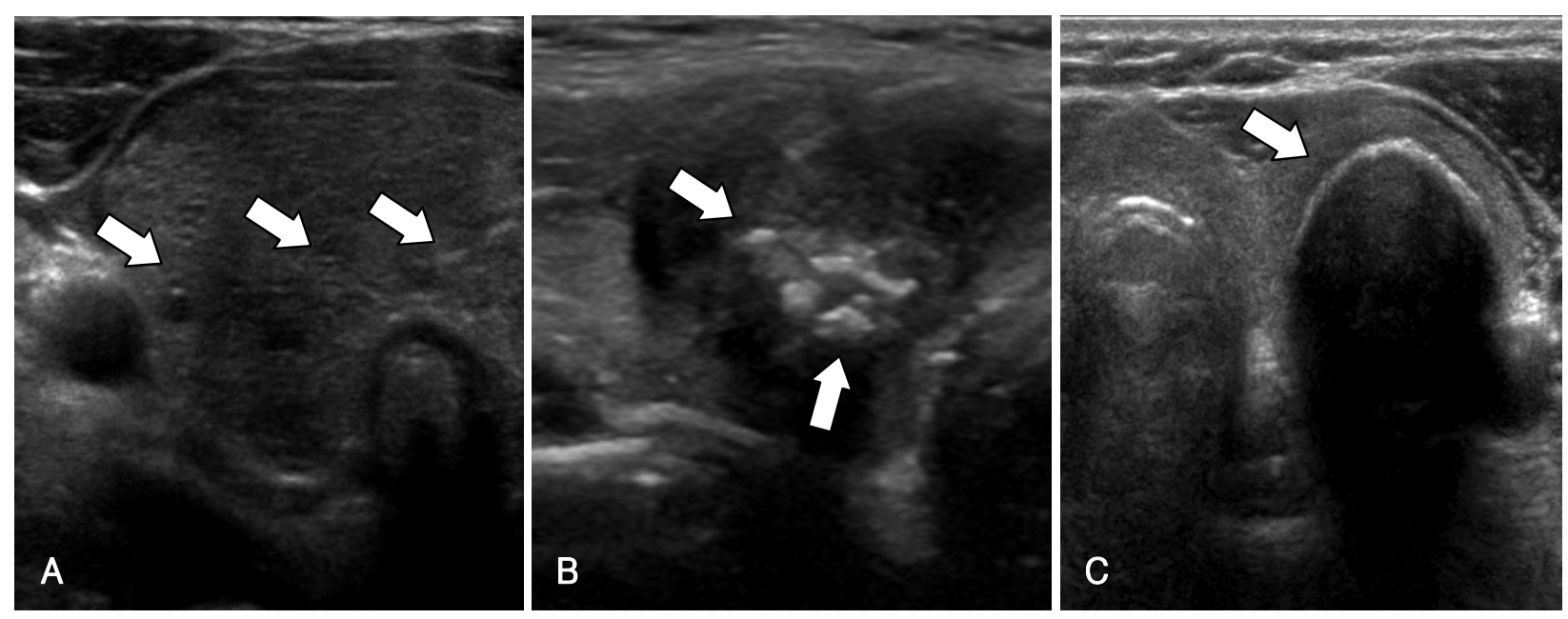

Fig. 1. Sonographic patterns of calcification. Microcalcification: US image shows multiple punctate bright echoes (arrow) without shadowing in a hypoechoic tumor (A). Focal coarse calcification: US image shows a bright echo (arrow) with shadowing in a well defined, isoechoic tumor with halo (B). Rim calcification: US image shows bright echo (arrow) surrounding a tumor (C). US: ultrasonography. 
였다. 전산화단층촬영을 시행한 환자 110 명에서는 석회화 가 30예(27.3\%)에서 관찰되었고 그 중 결절 내 석회화는 26 예(86.7\%), 변연부 석회화는 4예(13.3\%)였다(Fig. 2). 경부 초음파검사와 전산화단층촬영을 모두 시행한 90 예 중 초음파검사 38예(42.2\%), 전산화단층촬영 24예(26.7\%) 에서 석회화가 관찰되었으며, 그 중 25.6\%(90예 중 23예) 는 두 검사에서 모두 석회화를 확인할 수 있었다. 석회화 를 보인 결절 중 유두상암은 초음파검사에서 34예(82.9\%), 전산화단층촬영에서 20예(66.7\%) 였으며, 초음파검사에서 석회화를 보인 양성 결절은 갑상선 결절성 비대증이 4 예

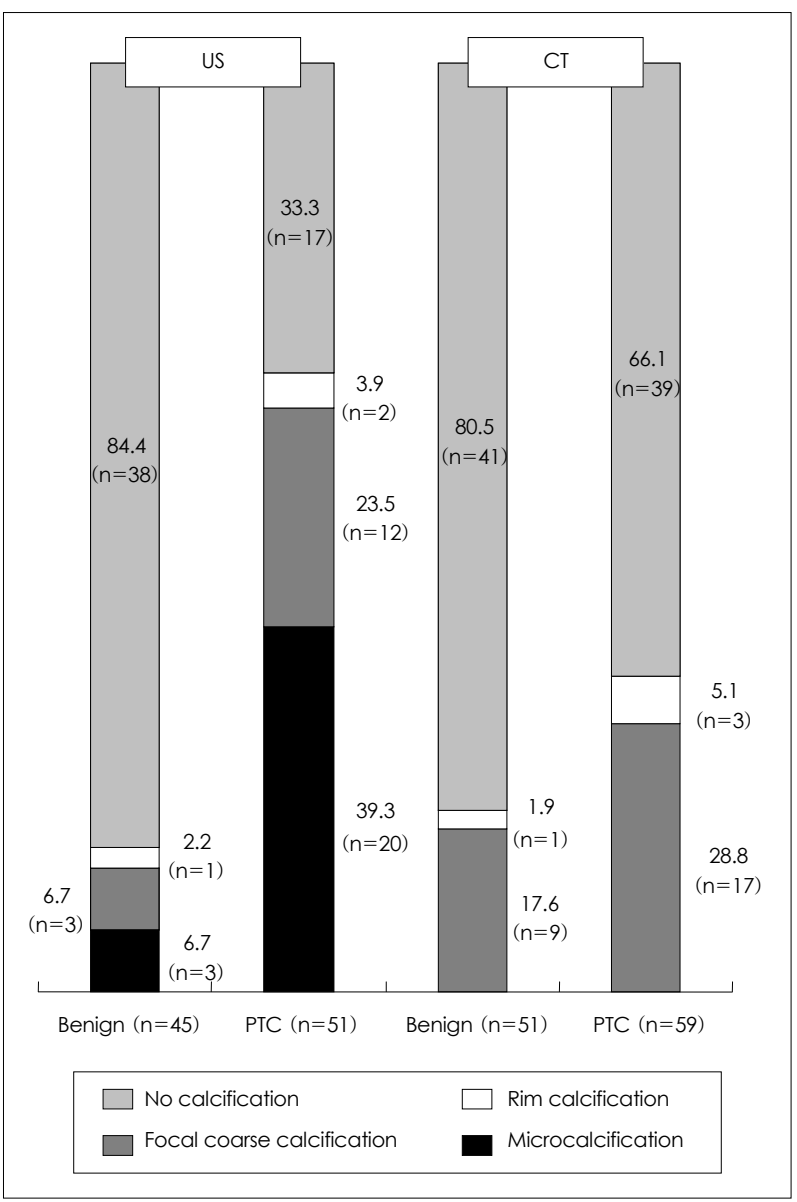

Fig. 2. Incidence (\%) of calcification in ultrasonography (US) and computed tomography (CT). PTC: papillary thyroid cancer.
로 가장 많았고 여포상 비대증이 2예, 선종성 비대증이 1 예 순이었다.

초음파검사상 석회화가 관찰된 군과 관찰되지 않은 군에서 유두상암이 차지하는 비율은 각각 $82.9 \%, 30.9 \%$ 였고, 유 두상암에 대한 석회화의 교차비는 9.237 (95\% Confidence interval(CI), 3.56 23.91)로 통계적으로 유의한 차이를 보였다 $(p=.000)$. 그러나 전산화단층촬영에서 관찰된 석회 화와 유두상암의 연관성은 통계적으로 유의하지 않았으며 $(p=.09)$, 교차비도 2.075(95\% CI, 0.86 4.98)로 유의하 지 않았다.

석회화 유형 중 미세석회화는 초음파검사를 시행한 양성 결절 45예 중 3예(6.7\%)에서 관찰되었고 유두상암 51예 중 20예(39.2\%)에서 나타났으며, 초음파검사를 통해 미세 석회화를 확인한 전체 갑상선 종물 23예 중 20예(87.0\%) 에서 유두상암이 진단되어 통계적으로 높은 유의도를 보였 다 $(p=.000)$. 국소 석회화와 변연부 석회화는 각각 $80.0 \%$ (15예 중 12예), $66.6 \%$ (3예 중 2예)의 유두상암 빈도를 보였으나 통계적인 유의성은 없었다 $(p=.06, p=.46)$. 미세 석회화의 유두상암 발생 위험도를 구하기 위한 유두상암과 미세석회화의 교차비는 7.556(95\% CI, 2.30 24.75)로 통계적으로 유의하였다(Table 1).

\section{환자의 연령에 따른 갑상선 종물 내 석회화와 유두상암과 의 연관성}

갑상선 석회화를 보인 군의 평균연령은 52.0세였으며 석 회화 소견이 없는 군의 평균연령은 48.0세였다. 40세 미만 군(23명)과 40세 이상군(73명)으로 나누었을 때, 초음파 검사에서 석회화 소견을 보인 환자 중 유두상암으로 진단된 환자는 40세 미만군에서 90.9\%(11예 중 10예), 이상군에 서 80.0\%(30예 중 24예)였으며 두 군 모두 통계적으로 석회화와 유두상암은 유의하였다(40대 미만군 $p=.04,40$ 대 이상군 $p=.001)$. 유두상암 발생에 대한 석회화의 교차 비는 40대 미만군에서는 7.778(95\% CI, 1.20 50.42), 40 대 이상군에서는 5.538(95\% CI, 2.01 15.24)로 각각 통 계적 유의성을 보였다(Table 2).

Table 1. Correlation between calcification detacted by sonography and pathologic diagnosis

\begin{tabular}{|c|c|c|c|c|c|c|}
\hline \multirow{2}{*}{ Sonographic finding } & \multicolumn{2}{|c|}{ Pathology (\%) } & \multirow{2}{*}{ Total (\%) } & \multirow{2}{*}{ Odds ratio } & \multirow{2}{*}{$95 \% \mathrm{Cl}$} & \multirow{2}{*}{ p-value } \\
\hline & PTC & Benign & & & & \\
\hline Calcification (+) & $34(82.9)$ & $7(17.1)$ & $41(100)$ & \multirow{2}{*}{9.237} & \multirow{2}{*}{$3.56-23.91$} & \multirow{2}{*}{$\mathrm{p}<.05$} \\
\hline Calcification $(-)$ & $17(30.9)$ & $38(69.1)$ & $55(100)$ & & & \\
\hline Microcalcification $(+)$ & $20(87.0)$ & $3(13.0)$ & $23(100)$ & \multirow{2}{*}{7.556} & \multirow{2}{*}{$2.30-24.75$} & \multirow{2}{*}{$p<.05$} \\
\hline Microcalcification $(-)$ & $31(42.5)$ & $42(57.5)$ & $73(100)$ & & & \\
\hline
\end{tabular}

PTC: papillary thyroid cancer, $\mathrm{Cl}$ : confidence initerval 
Table 2. Correlation between calcification and pathologic diagnosis by patient age

\begin{tabular}{|c|c|c|c|c|c|c|c|}
\hline \multirow{2}{*}{ Patinet age } & \multirow{2}{*}{ Sonographic finding } & \multicolumn{2}{|c|}{ Pathology (\%) } & \multirow{2}{*}{ Total (\%) } & \multirow{2}{*}{ Odds ratio } & \multirow{2}{*}{$95 \% \mathrm{Cl}$} & \multirow{2}{*}{ p-value } \\
\hline & & PTC & Benign & & & & \\
\hline \multirow[t]{2}{*}{$<40$ years $(n=23)$} & Calcification (+) & $10(90.9)$ & $1(9.1)$ & $11(100)$ & 7.778 & $1.20-50.42$ & $p<.05$ \\
\hline & Calcification $(-)$ & $4(26.7)$ & $11(73.3)$ & $15(100)$ & & & \\
\hline \multirow[t]{2}{*}{$\geq 40$ years $(n=73)$} & Calcification $(+)$ & $24(80.0)$ & $6(20.0)$ & $30(100)$ & 5.538 & $2.01-15.24$ & $p<.05$ \\
\hline & Calcification (-) & $13(32.5)$ & $27(67.5)$ & $40(100)$ & & & \\
\hline
\end{tabular}

PTC: papillary thyroid cancer, $\mathrm{Cl}$ : confidence initerval

\section{고 찰}

갑상선 결절은 비교적 흔한 질환으로 부검이나 고해상도 초음파로 관찰 시 성인의 약 $50 \%$ 는 갑상선에 결절을 가 지고 있는 것으로 추정된다. ${ }^{1,2)}$ 그러나 이 중 악성의 가능 성은 $10 \%$ 이내로 보고되고 있어 갑상선 결절을 진단, 치 료시 양성과 악성의 감별은 불필요한 수술을 피하기 위해 매우 중요하다. ${ }^{3)}$ 경부 초음파검사는 현재 갑상선 결절을 찾 아내고 진단하는 데 가장 민감한 영상검사법으로, 세침흡 인검사를 같이 시행함으로써 매우 정확한 진단을 내릴 수 있다. ${ }^{8)}$ 이와 함께 전산화단층촬영은 갑상선 결절과 종격동 종양을 감별하며 악성 결절의 림프절 전이 여부와 기도침 범 여부의 감별, 수술 전 해부학적 구조와 변이 관찰에 유 용하게 이용된다. ${ }^{9)}$ 그러나 경부 초음파검사와 전산화단층 촬영의 경우에 결절의 특성 즉, 양성과 악성을 확진할 만한 기준이 없기 때문에 정확한 진단 수단은 되지 못한다. 하 지만 양성 혹은 악성 결절의 어느 한 편에 자주 나타나는 성향들을 분석함으로써 결절의 특성을 예측하는 데 도움을 줄 수 있다.

갑상선 결절의 초음파검사 소견 중 악성 종양을 시사하 는 소견은 후방 음영증강을 동반하지 않은 저음영의 결절, 앞뒤가 긴 모양(taller than wide), 불완전하고 불규칙한 변 연부 달무리(halo)를 가진 결절, 불분명한 경계를 가진 결 절, 석회화, 단독성 결절, 낭성 성분이 $50 \%$ 이하인 혼합성 결절, 갑상선 주변 구조의 침범, 경부 림프절 종대 등이 다. ${ }^{6,10,11)}$ 그 중 특히 미세석회화는 다른 소견들보다 더 특 이적으로 악성 결절과 관계가 있어, 나이가 젊은 환자에서 단독 결절이면서 미세석회화가 보인다면 대부분 악성이었 다는 보고도 있다. ${ }^{5,12)}$ 본 연구에서는 새로운 진단 기준을 추가로 보고하는 것은 아니지만, 갑상선 수술을 시행한 환 자들을 모집단으로 술 전 초음파검사와 전산화단층촬영에 서 관찰된 석회화의 유형을 비교, 분석하고 술 후 병리조 직검사상 유두상암과의 연관성, 연령에 따른 연관성, 전산 화단층촬영과의 비교 등을 분석하여 여러 석회화 양상 중 초음파검사에서 발견된 미세석회화가 유두상암과 더 유의
한 연관을 보이는지를 확인하였다.

경부 초음파검사에서 갑상선의 석회화는 갑상선 결절 중 약 10 40\%의 다양한 빈도로 관찰이 된다고 알려져 있으 며, ${ }^{6,13)}$ 본 연구에서는 $42.7 \%$ (96예 중 41예)에서 관찰되 었다. 또한 미세석회화는 결절의 약 10 35\%에서 발견되 며, ${ }^{4,7,13)}$ 본 연구에서는 $24.0 \%$ (96예 중 23예) 에서 관찰이 되어 이전의 문헌들과 비슷한 결과를 보였다. 갑상선 석회 화 소견과 악성 결절의 높은 연관성에 대해 보고한 최근 문헌 ${ }^{3,12,13)}$ 들과 마찬가지로 본 연구에서도 석회화와 유두 상암은 유의한 상관관계를 보였다. 석회화를 보인 갑상선 결 절은 통계적으로 유의하게 유두상암이 많이 발견되었으며 (82.9\%), 유두상암은 양성 결절에 비하여 높은 석회화 빈 도 $(66.7 \%)$ 를 보여 석회화와 유두상암의 높은 연관성을 확 인할 수 있었다. 교차비를 이용한 위험도 산출에서 석회화 가 있는 군은 없는 군에 비해 유두상암이 발견될 확률이 9 배 높다는 결과가 나왔는데, 이것은 이전에 보고된 4 배보 다 높은 수치였다. ${ }^{14)}$ 양성 결절에서도 빈도는 낮지만 석회 화를 관찰할 수 있었으며 $(15.6 \%)$, 이는 이전의 문헌 ${ }^{14)}$ 보 다는 낮은 수치이나, 양성 결절 중 다발성 결절성 비대증 에서의 가장 높은 발견율은 같았다. 그렇지만 술 전 검사 에서 양성 결절이 강하게 의심되는 경우에는 수술을 시행 치 않고 정기적 관찰만 하는 경우가 많아 현실적으로 수술 을 받아 조직병리학적으로 확진된 환자군만을 모집단으로 한정한 본 연구에서는 양성 결절의 특성 분석에 한계점이 있을 수 있다.

다양한 석회화 양상과 유두상암의 관계에 대한 많은 연 구가 이루어져 왔다. Solbiati 등드는 유두상암에서 갑상선 미세석회화의 민감도와 특이도가 각각 $55 \%, 95 \%$ 로 암종 의 대부분에서 미세석회화를 동반하는 것은 아니나 미세석 회화가 관찰되지 않을 경우 암종의 가능성이 낮아질 수 있 음을 시사하였다. Choi 등ㅇ)은 갑상선 내의 점상으로 보이는 미세한 석회화가 유두상암의 특징이며 이것은 조직병리 소 견으로 관찰되는 psammoma body로 생각된다고 보고하였 다. Solbiati 등 ${ }^{16)}$ 은 초음파검사 중 종양 내부의 미세석회화 가 유두상암과 수질성암 등 갑상선 암종의 거의 대부분에서 
발견되며 석회화가 관찰되지 않을 경우 암종의 가능성이 낮아진다고 하였지만, 이에 대해 Hatabu 등 ${ }^{17)}$ 은 미세석회 화의 초음파검사를 통해 발견하는 민감도가 상대적으로 낮 고 밀집된 섬유화나 교질을 미세석회화로 판정할 수 있어 임상에서 사용 시 제약이 따른다고 보고하였다. 본 연구에 서는 석회화 유형에 따른 유두상암의 연관성을 알아보기 위해 초음파검사에서 관찰되는 석회화 유형을 미세석회화, 국소 석회화, 변연부 석회화로 나누었으며 세 유형 중 미세 석회화만이 통계적으로 유두상암과 유의한 연관을 보였다 $(p=.000)$. 미세석회화가 관찰된 결절군 중 $87.0 \%$ 에서 유 두상암이 발견되었으며 미세석회화가 관찰되지 않은 결절 군에서는 $42.5 \%$ 에서 유두상암이 발견되어 높은 유의도를 확인할 수 있었다. 또 교차비를 통한 미세석회화와 유두상 암 발생률의 관계를 산출한 결과, 미세석회화 존재시 8 배 높은 위험도를 보였다.

갑상선 결절에 대한 세침흡인검사와 초음파검사의 진단 정확도 비교에 대해서는 현재까지 많은 논란이 있어 왔다. Watters 등 ${ }^{6}$ 은 갑상선 결절에서 초음파검사가 세침흡인검 사보다 진단율이 더 높다고 보고하였으며, Yang 등 ${ }^{18)}$ 은 세 침흡인검사의 중요성에 대해 강조하는 등 현재 서로 보완 적 관계의 필수적 검사로 인식이 되고 있다. ${ }^{4)}$ 본 연구에서 유두상암의 경우 술 전 시행한 세침흡인검사에서 95.2\%(62 예 중 59예)가 유두상암을 진단할 수 있었으며 2예는 양 성 결절, 1 예는 두 번의 세침흡인검사에서 검체 불충분 판 정을 보였다. 양성 결절의 경우 검체 불충분 등으로 진단 이 불가능한 경우가 $37.0 \%$ (54예 중 20예)였으며, 양성 혹은 악성으로 확인된 경우 세침흡인검사 결과와 최종 병 리조직학적 결과의 차이는 보이지 않았다. 세침흡인검사의 성공률과 진단의 정확도는 석회화의 유무, 유형과는 특별한 연관성을 찾을 수 없었다.

갑상선 석회화의 빈도는 고령에서 더 증가하는 것으로 알 려져 있으며, 원인으로는 연령 증가에 따른 조직의 퇴행성 괴사로 인한 이영양성 석회화가 가장 흔하고, 이외에 부갑 상선 기능항진증, 고비타민 $\mathrm{D}$ 혈증, 종양성 퇴화 등이 거론 되고 있다. ${ }^{14,19)}$ Kakkos 등 ${ }^{14)}$ 은 40세 미만군과 이상군으 로 나누었을 때 40세 미만군은 암종 진단의 민감도는 떨 어지나 양성예측도, 특이도, 비교 위험도는 더 높이 측정되 었으며, 이는 석회화 소견이 있는 40 대 미만 집단은 같은 연령의 석회화 소견이 없는 집단보다 암종 발생률이 4 배 높다는 것을 의미한다고 하였다. 본 연구에서 석회화 소견 을 보인 군은 석회화 소견이 없는 군보다 평균연령이 높았 으며, 40세를 기준으로 나누었을 때 양 군 모두 석회화와 유두상암이 통계적으로 높은 유의성을 보였다. 교차비를
Table 3. Accuracy of detected calcifications in the diagnosis of thyroid nodule by imaging modality

\begin{tabular}{lcc}
\hline & \multicolumn{2}{c}{ Imaging modality } \\
\cline { 2 - 3 } & Ultrasonography & CT \\
\hline Sensitivity (\%) & 65 & 32 \\
Specificity (\%) & 82 & 81 \\
Positive predictive value (\%) & 76 & 60 \\
Negative predictive value (\%) & 74 & 57 \\
Odds ratio & 9.237 & 2.075 \\
\hline
\end{tabular}

CT: computed tomography

이용한 위험도 측정에서 40 대 미만군에서는 석회화 존재시 비석회화군보다 8 배, 40 대 이상군에서는 6 배 높은 유두암 종 발병 위험을 보여 이전 보고 ${ }^{14)}$ 보다 전체적으로 높은 위 험도를 보였고, 40대 미만군에서 더 높은 위험도를 보이는 것은 같은 추세를 따랐다.

갑상선 결절을 진단하기 위해 쓰이는 가장 대표적인 영상 학적 도구로 경부 초음파검사와 전산화단층촬영을 들 수 있 다. 이 중 갑상선 결절의 감별과 진단에는 경부 초음파검 사가 더 우수한 것으로 알려져 있으며, Koh 등ㄴ)은 갑상선 의 술 전 필수검사로 경부 초음파검사와 세침흡인검사를 꼽 았다. 전산화단층촬영이 갑상선 결절의 진단에 상대적으로 부정확한 이유는 해상도가 떨어지며 미세한 석회화를 단면 에서 놓칠 경우가 많고 불순물 효과 등에 의해 나타나는 오차 때문이다. ${ }^{4)}$ 또한 초음파검사는 의심 병변 발견시 다 양한 각도에서 압력을 주어가며 좀 더 주의 깊게 세밀히 관 찰 가능하다는 장점이 있다. 본 연구에서 경부 초음파검사 와 전산화단층촬영을 모두 시행한 90 예 중 초음파검사 38 예(42.2\%), 전산화단층촬영 24예(26.7\%)에서 석회화가 관 찰되었으며, 그 중 $25.6 \%$ (90예 중 23예)는 두 검사에서 모두 석회화를 확인할 수 있었다. 전산화단층촬영에서 관 찰된 석회화와 유두상암의 연관성은 위험도가 2 배 높았으 나 경부 초음파검사와는 달리 통계적으로 유의하지 않았으 며 민감도, 특이도, 양성예측도, 음성예측도 모두 경부 초 음파검사보다 떨어졌다(Table 3).

\section{REFERENCES}

1) Yang YS, Lim HS, Kim YW, Oh JK, Hong KH. The relative risk of cancer in sonographically detected thyroid nodules with calcifications. Korean J Otolaryngol-Head Neck Surg 2004;47 (5) :457-61.

2) Simeone JF, Daniels GH, Mueller PR, Maloof F, vanSonnenberg E, Hall DA, et al. High resolution real time sonography of the thyroid. Radiology 1982;145(2):431-5.

3) Koike E, Noguchi S, Yamashita H, Murakami T, Ohshima A, Kawamoto H, et al. Ultrasonographic characteristics of thyroid nodules: prediction of malignancy. Arch Surg 2001;136 (3):334-7.

4) Koh JW, Shin JC, Kim HZ, Park SK. Clinical significance of preoperative studies in diagnosis of thyroid nodule-FNAC, ultrasonography, computed tomography. Korean J Otorhinolaryngol-Head Neck Surg 
2000;43(3):323-8.

5) Iannuccilli JD, Cronan JJ, Monchik JM. Risk for malignancy of thyroid nodules as assessed by sonographic criteria: the need for biopsy. J Ultrasound Med 2004;23 (11):1455-64.

6) Watters DA, Ahuja AT, Evans RM, Chick W, King WW, MEtrewel $\mathrm{C}$, et al. Role of ultrasound in the management of thyroid nodules. Am J Surg 1992;164(6):654-7.

7) Chammas MC, de Araujo Filho VJ, Moysés RA, Brescia MD, Mulatti GC, Brandão LG, et al. Predictive value for malignancy in the finding of microcalcifications on ultrasonography of thyroid nodules. Head Neck 2008; 30 (9):1206-10.

8) Chammas MC, Gerhard R, de Oliveira IR, Widman A, de Barros N, Durazzo M, et al. Thyroid nodules: evaluation with power Doppler and duplex Doppler ultrasound. Otolaryngol Head Neck Surg 2005;132 (6) :874-82.

9) Cheun HO, Kim KH, Kang YI, Kong SK. A clinical rewiew of surgically treated thyroid nodules. J Korean Surg Soc 1998;54 (2):172-82.

10) Choi YJ, Kim SM, Choi SI. Diagnositic accuracy of ultrasound features in thyroid microcarcinoma. Endocr J 2008;55 (5):931-8.

11) Kim EK, Park CS, Chung WY, Oh KK, Kim DI, Lee JT, et al. New sonographic criteria for recommending fine-needle aspration biopsy of nonpalpable solid nodules of the thyroid. AJR Am J Roentgenol $2002 ; 178(3): 687-91$.

12) Takashima S, Fukuda H, Nomura N, Kishimoto H, Kim T, Kobayashi
T. Thyroid nodules: re-evaluation with ultrasound. J Clin Ultrasound $1995 ; 23$ (3):179-84.

13) Kuma K, Matsuzuka F, Kobayashi A, Hirai K, Morita S, Miyauchi A, et al. Outcome of long standing solitary thyroid nodules. World J Surg 1992;16 (4):583-7.

14) Kakkos SK, Scopa CD, Chalmoukis AK, Karachalios DA, Spiliotis JD, Harkoftakis JG, et al. Relative risk of cancer in sonographically detected thyroid nodules with calcifications. J Clin Ultrasound 2000; $28(7): 347-52$

15) Solbiati L, Cioffi V, Ballarati E. Ultrasonography of the neck. Radiol Clin North Am 1992;30 (5) :941-54.

16) Solbiati L, Ballarati E, Cioffi V. Microcalcifications- A clue in the diagnosis of thyroid malignancies. $1^{\text {st }}$ ed. Chicago: Proceedings of the $76^{\text {th }}$ Meeting of Radiologic Society of North America;1990. p.140-3.

17) Hatabu H, Kasagi K, Yamamoto K, Iida Y, Misaki T, Hidaka A, et al. Cystic papillary carcinoma of the thyroid gland: a new sonographic sign. Clin Radiol 1991;43 (2):121-4.

18) Yang GC, LiVolsi VA, Baloch ZW. Thyroid microcarcinoma: fineneedle aspiration diagnosis and histologic follow-up. Int J Surg Pathol 2002;10 (2):133-9.

19) Yamana K, Nakano R, Kinoshita T, Morimatsu M, Nakashima T. Ultrastructure of anaplastic carcinoma (spindle and giant cell type) with large calcification in the thyroid gland. Acta Pathol Jpn 1984;34 (3) :585-92. 